This item was submitted to Loughborough's Research Repository by the author.

Items in Figshare are protected by copyright, with all rights reserved, unless otherwise indicated.

\title{
Fluid catalytic cracking unit emissions and their impact
}

PLEASE CITE THE PUBLISHED VERSION

http://www.springerlink.com/

PUBLISHER

(c) Springer Verlag

VERSION

AM (Accepted Manuscript)

LICENCE

CC BY-NC-ND 4.0

REPOSITORY RECORD

Yateem, Wael, Vahid Nassehi, and Abdul R. Khan. 2011. "Fluid Catalytic Cracking Unit Emissions and Their Impact". figshare. https://hdl.handle.net/2134/8979. 
This item was submitted to Loughborough's Institutional Repository (https://dspace.lboro.ac.uk/) by the author and is made available under the following Creative Commons Licence conditions.

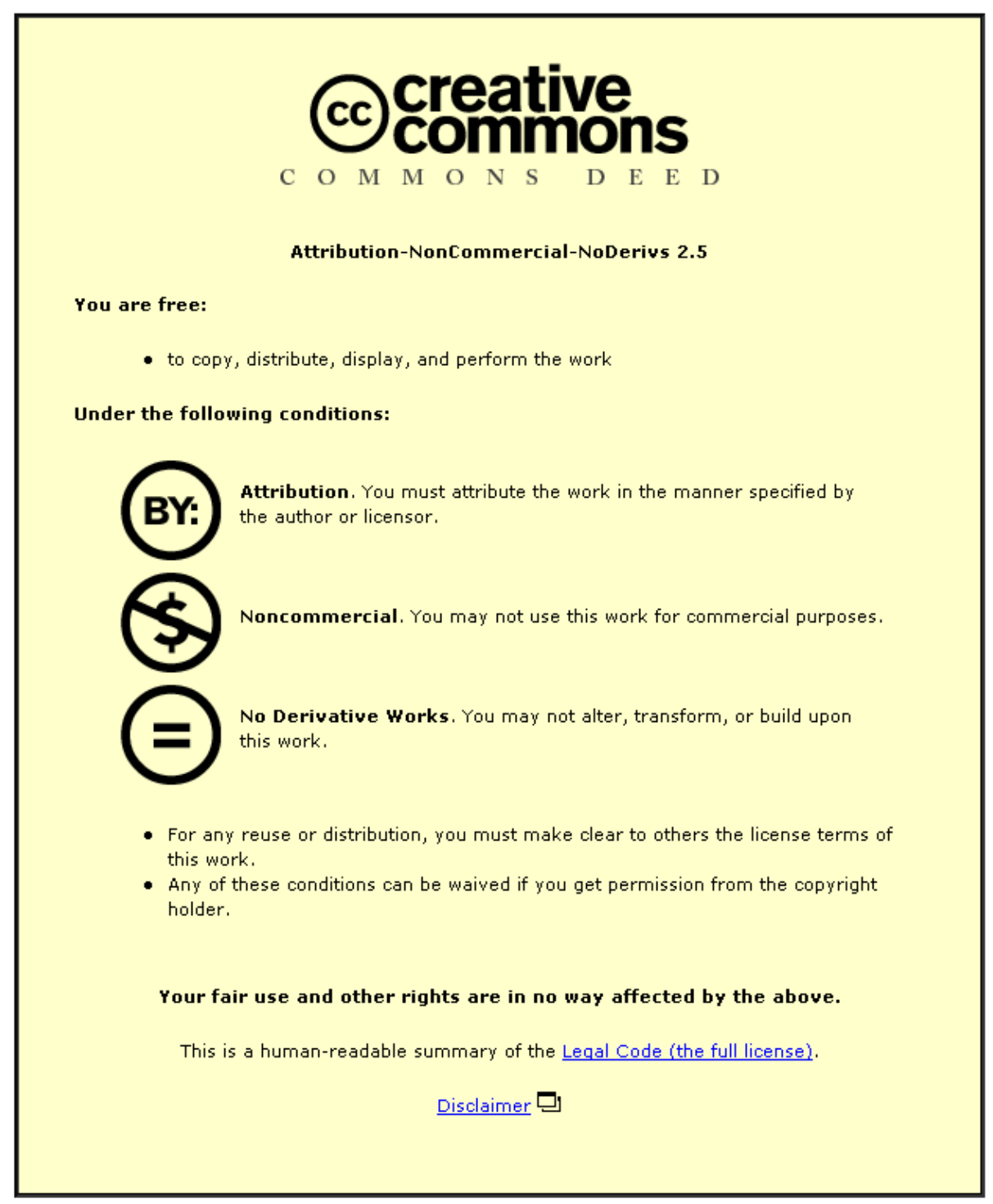

For the full text of this licence, please go to: http://creativecommons.org/licenses/by-nc-nd/2.5/ 


\title{
Fluid catalytic cracking unit emissions and their impact
}

Wael Yateem ${ }^{1}$, Vahid Nassehi ${ }^{1}$, Abdul R. Khan $^{2}$

${ }^{1}$ Department of Chemical Engineering, Loughborough University, Leicestershire, UK, LE11 3TU.

${ }^{2}$ Department of Environment Technology and Management, College for Women, Kuwait University, Kuwait

\begin{abstract}
Fluid catalytic cracking unit is of great importance in petroleum refining industries as it treats heavy fractions from various process units to produce light ends (valuable products). FCC unit feedstock consists of heavy hydrocarbon with high sulphur contents and the catalyst in use is zeolite impregnated with rare earth metals i.e. Lanthanum and Cerium. Catalytic cracking reaction takes place at elevated temperature in fluidized bed reactor generating sulphur-contaminated coke on the catalyst with large quantity of attrited catalyst fines. In the regenerator, coke is completely burnt producing $\mathrm{SO}_{2}, \mathrm{PM}$ emissions. The impact of the FCC unit is assessed in the immediate neighborhood of the refinery. Year long emission inventories for both $\mathrm{SO}_{2}$ and $\mathrm{PM}$ have been prepared for one of the major petroleum refining industry in Kuwait. The corresponding comprehensive meteorological data are obtained and preprocessed using Aermet (Aermod preprocessor). US EPA approved dispersion model, Aermod is used to predict ground level concentrations of both pollutants in the selected study area. Model output is validated with measured values at discrete receptors and an extensive parametric study has been
\end{abstract}


conducted using three scenarios, stack diameter, stack height and emission rate. It is noticed that stack diameter has no effect on ground level concentration, as stack exit velocity is a function of stack diameter. With the increase in stack height, the predicted concentrations decrease showing an inverse relation. The influence of the emission rate is linearly related to the computed ground level concentrations.

Keywords: Dispersion model, Aermod, emissions, FCC, pollutants exeedance

\section{Introduction}

Fluid catalytic cracking (FCC) of heavy ends into high value liquid fuels is a common practice in the oil refining industry. In this process the heavy feedstock containing sulphur as a major contaminant is cracked to light products. Sulphur is redistributed in the liquid and gaseous products and coke on the catalyst. In the regenerator coke with sulphur contamination is completely burnt and flue gas containing $\mathrm{SO}_{2}$ is discharged. In the present work, a comprehensive emission inventories from FCC unit in an oil refinery have been prepared. These inventories are calculated based on complete combustion of sulphur and coke impregnated on the catalyst in the regenerator. Mainly for both $\mathrm{SO}_{2}$ and particulate matters (PM) emission rates are calculated accurately using material balance for a yearlong period considering seasonal variations in the operation of the process unit in one of the main refinig industry in Kuwait, Yateem et al., (2010). These results reflect the variation of sulphur in feedstock that comes from various refinery units. $\mathrm{SO}_{2}$ and $\mathrm{PM}$ emission inventories are completed and used in dispersion model to assess their impact on the immediate surroundings of the refinery.

The most advanced dispersion model AERMOD has been selected for prediction ground level concentration of $\mathrm{SO}_{2}$ and $\mathrm{PM}$ based on comprehensive year long emission inventories of FCC unit. 
Aermod is a dispersion model that uses Gaussian distribution for the stable conditions and non-Gaussian probabilities density function for the unstable conditions. Aermod has two preprocessors; Aermet that provides planetary boundary layer parameters over a high altitude to yield accurate predicted concentration values for a given meteorological conditions. It can accommodate large meteorological data (multiple years). Aermap generates regular receptors over a given terrain for the evaluation of pollutants ground level concentrations.

The meteorological data for year 2008 are obtained and are used in preprocessor AERMET to generate planetary boundary layers parameters. These generated data are used in AERMOD for fixed emission rate to assess the influence of prevailing meteorological conditions at this particular site. AERMOD has been used for actual yearlong inventories to predict ground level concentrations and validate the model by comparing the results against the recorded values from Kuwait Environmental Public Authority (K-EPA) monitoring stations. 


\section{Background}

Heavy fractions from different refining units are cracked in FCC unit to useful products, generating $\mathrm{SO}_{2}$ and $\mathrm{PM}$ emissions. $\mathrm{SO}_{2}$ emission inventory is prepared from elemental sulphur balance over the unit, Yateem et al., (2010).

Whitcombe et al., (2003) showed the formation of fines in a fluidized catalytic cracker unit (FCCU) due to catalyst attrition and fracture as a major source of catalyst loss. The petroleum industry employs fluid catalytic cracking units (FCCUs) as the major tool to produce gasoline from crude oil. At the center of this unit is regenerator which is used to burn coke from the surface of the spend catalyst. As the regeneration process is very turbulent, a large amount of catalyst material is discharge to the atmosphere. In addition to the fine particles present in the catalyst, the turbulent conditions inside the FCC alter the particle size distribution of the catalyst generating fine particles and significant amount of aerosols, which has been identified in the stack emission of FCCUs

Caputo et al., (2003) conducted an inter-comparison between Gaussian, Gaussian segmented plumes and Lagrangian codes. Gaseous emissions are simulated under real meteorological conditions for dispersion models Aermod, HPDM, PCCOSYMA and HYSPLIT. The AERMOD and HPDM meteorological preprocessors results are analyzed and the main differences found are in the sensible heat flux (SHTF) and $\mathrm{u}^{*}$ (friction velocity) computation, which have direct effect on the Monin-Obukov length and mixing height calculation. Gaussian models (Aermod, HPDM) computed the dispersion parameters by using the similarity relationships, whereas Gaussian segmented model (PCCOSYMA) used P-G stability class to evaluate these parameters. Lagrangian transport model (HYSPLIT) advected the puff and calculated its growth rate with local mixing coefficients. Meteorological parameters have great effect on the performance of air dispersion models. Therefore, Aermod and HPDM have developed effective and sophisticated meteorological parameters preprocessors. It is noticed that HPDM computed the most stable condition and the lowest mixing height. The comparison also showed a significant discrepancy between HPDM and other Gaussian models. The 
maximum ground level concentration predicted by Aermod, HPDM and PCCOSYMA are similar.

Rama Krishna et al., (2004) examined the assimilative capacity and the dispersion of pollutants resulted from various industrial sources in the Visakhapatnam bowl area, which is situated in coastal Andhra Pradesh, India. Two different air dispersion models (Gaussian plume model, GPM and ISCST-3) are used to predict ground level concentrations of Sulphur Dioxide and oxides of Nitrogen and assimilative capacity of the Visakhapatnam bowl area's atmosphere for two seasons, namely, summer and winter. The computed 8-hr averaged concentrations of the two pollutants obtained from the GPM and ISCST-3 are compared with those monitored concentrations at different receptors in both seasons and the validation carried out through Q-Q plots. Both models outputs showed similar trend with the observed values from the monitoring stations. The GPM output showed over-prediction, whereas the ISCST-3 showed under-prediction in comparison with the observed concentrations. Terrain features and land/sea breeze influences are not considered in this study, which strongly affected the models outputs.

Venkatram et al., (2004) evaluated dispersion models for estimating ground level concentrations in the vicinity of emission sources in the urban area of university of California, Riverside. Aermod-PRIME and ISC-PRIME dispersion models are used to predict $\mathrm{SF}_{6}$ at different receptors, where $\mathrm{SF}_{6}$ is used as tracer in a simulated non-buoyant release from a small source in urban area. Both models output are compared with hourlyobserved concentrations. The comparison showed that both models overestimate the highest concentrations, whereas lower range of concentrations is underestimated. It is concluded that Aermod can predict reliable concentrations if turbulent velocity measurements are used to estimate plume dispersion.

Lopez et al., (2005) assessed the impact of natural gas and fuel oil consumption on the air quality in an Industrial Corridor, Mexico to determine the optimal NG and fuel oil required to reduce $\mathrm{SO}_{2}$ concentration. Air dispersion model Aermod is used to compute ground level concentration of $\mathrm{SO}_{2}$. Model output is then validated against $\mathrm{SO}_{2}$ field measurements. Different hypothetical emission scenarios are performed to examine the impact of NG and fuel oil mixture. The obtained results in this work indicate that 
dispersion model Aermod presented good correlation with the measured concentrations. It is also concluded that increasing $40 \%$ of $\mathrm{NG}$ consumption will reduce $\mathrm{SO}_{2}$ concentration by $90 \%$.

Kesarkar et al., (2007) studied the spatial variation of $\mathrm{PM}_{10}$ concentration from various sources over Pune, India. Guassian air pollutant dispersion model Aermod is used to predict the concentration of $\mathrm{PM}_{10}$. Weather research and forecasting (WRF) model is used to furnish Aermod with planetary boundary layer and surface layer parameters required for simulation. Emission inventory has been developed and field-monitoring campaign is conducted under Pune air quality management program of the ministry of Environment and Forests. This inventory is used in Aermod to predict $\mathrm{PM}_{10}$. A comparison between simulated and observed $\mathrm{PM}_{10}$ concentration showed that the model underestimated the $\mathrm{PM}_{10}$ concentration over Pune. However, this work is conducted over a short period of time, which is not sufficient to conclude on adequacy of regionally averaged meteorological parameters for driving Gaussian models such as Aermod.

Isakov et al., (2007) examined the usefulness of prognostic models output for meteorological observations. These models outputs are used for dispersion applications to construct model inputs. Dispersion model Aermod is used to simulated observed tracer concentrations from Tracer Field Study conducted in Wilmington, California in 2004. Different meteorological observations sources are used i.e. onsite measurements, National Weather Services (NWS), forecast model output from ETA model and readily available and more spatially resolved forecast model from MM5 prognostic model. It is noted that MM5 with higher grid resolution than ETA performed better in describing sea breeze related to flow patterns observed and provided adequate estimates of maximum mixed layer heights observed at the site. It is concluded that MM5 and ETA prognostic models provided reliable meteorological inputs for dispersion models such as Aermod, because wind direction estimates from forecast models are not reliable in coastal areas and complex terrain. Therefore, comprehensive prognostic meteorological models can replace onsite observations or NWS observations.

Abdul Wahab et al., (2002) studied the impact of $\mathrm{SO}_{2}$ emissions from a petroleum refinery on the ambient air quality in Mina Al-Fahal, Oman. Dispersion model ISCST is 
used to predict $\mathrm{SO}_{2}$ ground level concentration. The study is performed over a period of 21 days. Computed $\mathrm{SO}_{2}$ concentrations are compared with the measured values of $\mathrm{SO}_{2}$ for maximum hourly average concentration, maximum daily concentration and total period average concentration. It is noted that the model output under-predicted the $\mathrm{SO}_{2}$ concentration for all the three cases due to unavailability of background concentrations and the presence of more dominant sources. Based on the maximum daily average concentration and the total period maximum concentration, the model under-predicted the average measured concentration by $31.77 \%$ and $41.8 \%$ respectively. The model performed slightly better based on maximum hourly average concentration and underpredicted by $10.5 \%$.

Zou et al; (2010) evaluated the performance of Aermod in predicting $\mathrm{SO}_{2}$ ground level concentration in Dallas and Ellis counties in Texas as these two counties are populous and air pollution has been a concern. Two emission sources are considered in this study i.e. point sources and on-road mobile sources. Aermet is used to calculate the hourly planetary boundary layer parameters such as Monin-Obikhov length, convective scale, temperature scale, mixing height and surface heat flux. Dispersion model Aermod is used to simulate $\mathrm{SO}_{2}$ ground level concentration at different time scale i.e. $1 \mathrm{hr}$, $3 \mathrm{hr}$, 8hr, daily, monthly and annually for both counties separately. The results are validated with the observed concentrations. The results showed that Aermod performed well at the 8hr, daily, monthly and annual time scale when combined point and mobile emission sources are used in the simulation as model input. It is also noticed that Aermod is performed much better in simulating the high end of the spectrum of $\mathrm{SO}_{2}$ concentrations at monthly scale than at time scales of $1 \mathrm{hr}, 3 \mathrm{hr}, 8 \mathrm{hr}$ and daily.

Alrashidi et al; (2005) studied the locations of Kuwait Environmental Public Authority (K-EPA) monitoring station, which measure $\mathrm{SO}_{2}$ concentrations emitted from the power stations in the state of Kuwait. The major sources of $\mathrm{SO}_{2}$ emissions in Kuwait are from west Doha, east Doha, Shuwaikh, Shuaiba, and Az-Zour power stations. The Industrial Source Complex Short Term (ISCST3) dispersion model is used to predict $\mathrm{SO}_{2}$ ground level concentrations over residential areas. Yearlong meteorological data are obtained from Kuwait International Airport and used in the simulation of the dispersion 
model. Different discrete receptors in the residential areas are selected. It is observed that the weather pattern in Kuwait, specially the prevailing wind direction, has strong influence on the ground level concentration of $\mathrm{SO}_{2}$ in the residential areas located downwind of the both east and west Doha stations. The comparison between the predicted and the measured concentrations of $\mathrm{SO}_{2}$ from the monitoring stations located at the major populated areas showed that most of these monitoring stations locations are not adequate to measure $\mathrm{SO}_{2}$ concentrations emitted from the power stations. Therefore, relocation of the monitoring stations is highly recommended to accurately record the highest ground level concentrations of $\mathrm{SO}_{2}$ emitted from the power stations in Kuwait. 


\section{Model Application}

\subsection{Input Data}

Aermod dispersion model implementation requires three main input data. These are:

1. Source information: including pollutant emission rate (g/s), location coordinates in Universal Transverse Mercator (UTM) (m), base elevation from the sea level (m), stack height (m), exit stack inner diameter (m), exit stack gas velocity $(\mathrm{m} / \mathrm{s})$, and exit stack gas temperature $\left({ }^{\circ} \mathrm{K}\right)$.

2. Meteorological information for the region of interest: includes anemometer height $(\mathrm{m})$, wind speed $(\mathrm{m} / \mathrm{s})$, wind direction (flow vector from which the wind is blowing) (in degrees clockwise from the north), ambient air temperature $\left({ }^{\circ} \mathrm{C}\right.$ ), stability class at the hour of measurement (dimensionless) and hourly mixing height (m).

3. Receptor information: This can be specified or generated by the program to predict the pollutants’ concentrations at the selected receptors.

The entire required source input data are obtained from FCC unit in the refinery. A stack of $80 \mathrm{~m}$ height, an inner diameter of $2.3 \mathrm{~m}$, with an average exit gas velocity of $20 \mathrm{~m} / \mathrm{s}$ and exit gas temperature of $550{ }^{\circ} \mathrm{K}$ are fed into the model. Monthly emission variation is considered with total $\mathrm{SO}_{2}$ emission rate of $6089.2 \mathrm{~g} / \mathrm{s}$ and total PM emission rate of 302 $\mathrm{g} / \mathrm{s}$ as presented in detail (Yateem et al. 2010).

\subsection{Area of Study}

The area of study in this work covers portion of Ahmadi governorate in the state of Kuwait. Fahaheel area is adjacent to the petroleum refinery has one of the Kuwait EPA air quality monitoring station located at a polyclinic. Both areas Fahaheel and Ahmadi are surrounded by arid desert in the west side and bordered by the Gulf from the east.

Two different types of receptor coordinates are used as input to the Aermod model to 
predict the ground level concentration of $\mathrm{SO}_{2}$, these are:

1. Discrete Cartesian receptors specified at the sensitive areas viz., a school, a shopping area and EPA monitoring stations in Fahaheel. A hospital and petroleum services companies' offices are selected in Ahmadi.

2. Uniform Cartesian Grid receptors covering the entire area of study, where the FCC stack (emissions source) is located almost in the center of the mesh grid.

The receptors selected are based on the actual sites in a UTM location coordinate of the area of interest map. Table 1 shows the selected discrete receptors information.

The uniform grid receptors of a total 1764 (42 $\mathrm{x} 42)$ were divided into $(\Delta \mathrm{x}=300 \mathrm{~m} \mathrm{x} \Delta \mathrm{y}$ $=250 \mathrm{~m}$ ) to cover about $12 \times 10 \mathrm{~km}$ area of study. The optimum selection of the mesh size is based on the computational accuracy and time.

Table1. The selected discrete receptors information

\begin{tabular}{|c|c|c|c|}
\hline $\begin{array}{c}\text { ID } \\
\text { Number }\end{array}$ & Discrete receptor identity & X-coordinate & Y-coordinate \\
\hline 1 & Fahaheel Polyclinic & 219854.25 & 3219765.79 \\
\hline 2 & Petroleum Services Offices in Ahmadi & 216666.87 & 3220105.63 \\
\hline 3 & School in Fahaheel & 220300.00 & 3219820.85 \\
\hline 4 & Ahmadi Hospital & 213458.86 & 3221523.64 \\
\hline 5 & Shopping area in Fahaheel & 219274.32 & 3219554.21 \\
\hline
\end{tabular}

\section{Results And Discussion}

A yearlong comprehensive metrological data are processed by AERMET to generate boundary layer parameters and to pass all meteorological observations to AERMOD.

Figure 1 shows wind direction and magnitude for a period of year 2008. It is observed that most of the time; the prevailing wind direction is from North West. There is strong influence from the neighboring Gulf as the refinery is located at the coast, resulting into strong sea breeze blowing from East direction. Wind class frequency distribution for the entire year confirming $2 \%$ calm conditions, while $39.8 \%$ is between $3.6-5.7 \mathrm{~m} / \mathrm{s}$. the highest wind class $8.8-11.1 \mathrm{~m} / \mathrm{s}$ is less than $1 \%$. 


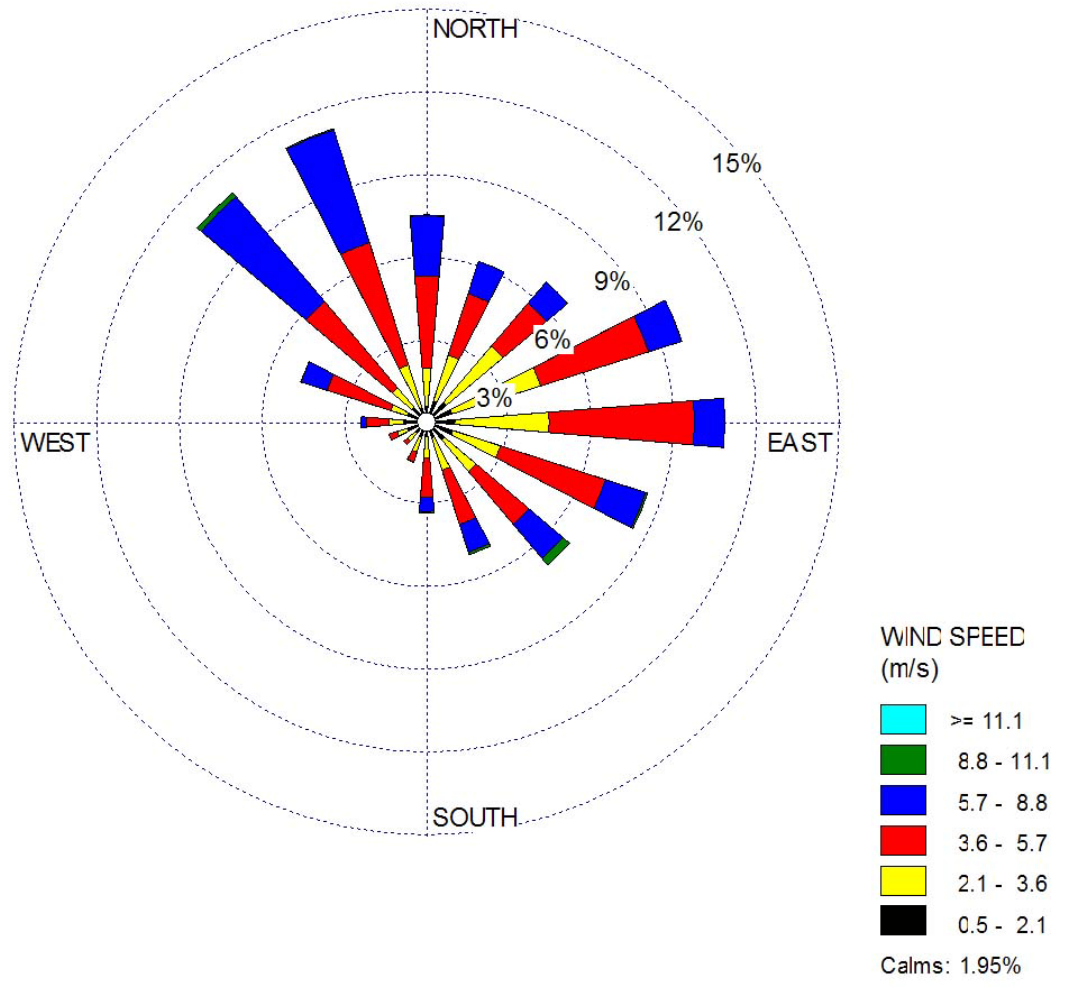

Fig. 1 wind rose for a period of year 2008

A model run is performed for actual monthly emission variation with total annual $\mathrm{SO}_{2}$ emission rate of $6089.2 \mathrm{~g} / \mathrm{s}$ and total PM emission rate of $302 \mathrm{~g} / \mathrm{s}$ independently. Monthly emission factors for both pollutants are tabulated in Table 2 and 3 respectively.

A discrete receptor is selected at Kuwait Environmental Public Authority monitoring station located at polyclinic in Fahaheel area. Concentrations of $\mathrm{SO}_{2}, \mathrm{NO}_{\mathrm{x}}, \mathrm{H}_{2} \mathrm{~S}, \mathrm{O}_{3}, \mathrm{CO}$, $\mathrm{CO}_{2}$, methane, non-methane hydrocarbon, Benzene, Toluene, Xylenes, ethylbenzene, total suspended particulates and meteorological parameters are continuously recorded on hourly basis. 
Table $2 \mathrm{SO}_{2}$ monthly emission factors

\begin{tabular}{|c|c|c|c|c|c|}
\hline January & February & March & April & May & June \\
\hline 0.077 & 0.083 & 0.096 & 0.1 & 0.077 & 0.088 \\
\hline July & August & September & October & November & December \\
\hline 0.067 & 0.067 & 0.088 & 0.077 & 0.1 & 0.075 \\
\hline
\end{tabular}

Table 3 PM monthly emission factors

\begin{tabular}{|c|c|c|c|c|c|}
\hline January & February & March & April & May & June \\
\hline 0.093 & 0.097 & 0.091 & 0.079 & 0.079 & 0.083 \\
\hline July & August & September & October & November & December \\
\hline 0.064 & 0.063 & 0.085 & 0.079 & 0.079 & 0.1 \\
\hline
\end{tabular}

Hourly predicted ground level concentrations at specified discrete receptor showed large scatter due to variation in meteorological conditions and the recorded values influenced by the contribution of various emission sources, resulting into specific background concentration that has made the comparison impracticable. There is large fluctuation in the background concentration, which is difficult to quantify. Hence, zero background concentration has been assumed to resolve this uncertainty. Therefore, daily average measured concentrations of $\mathrm{SO}_{2}$ were compared with the daily-predicted concentrations to validate the model output.

Figure 2 shows the plot between the measured top 20 daily average values versus the daily predicted top 20 values at the discrete receptor, Kuwait-EPA monitoring station.

The slope is equal to 0.72 , reflecting high measured values compared to predicted values, depicting the contribution of other emission sources. The correlation coefficient is equal to 0.91 reflecting an acceptable validation of the model output with measured average daily $\mathrm{SO}_{2}$ concentrations. 


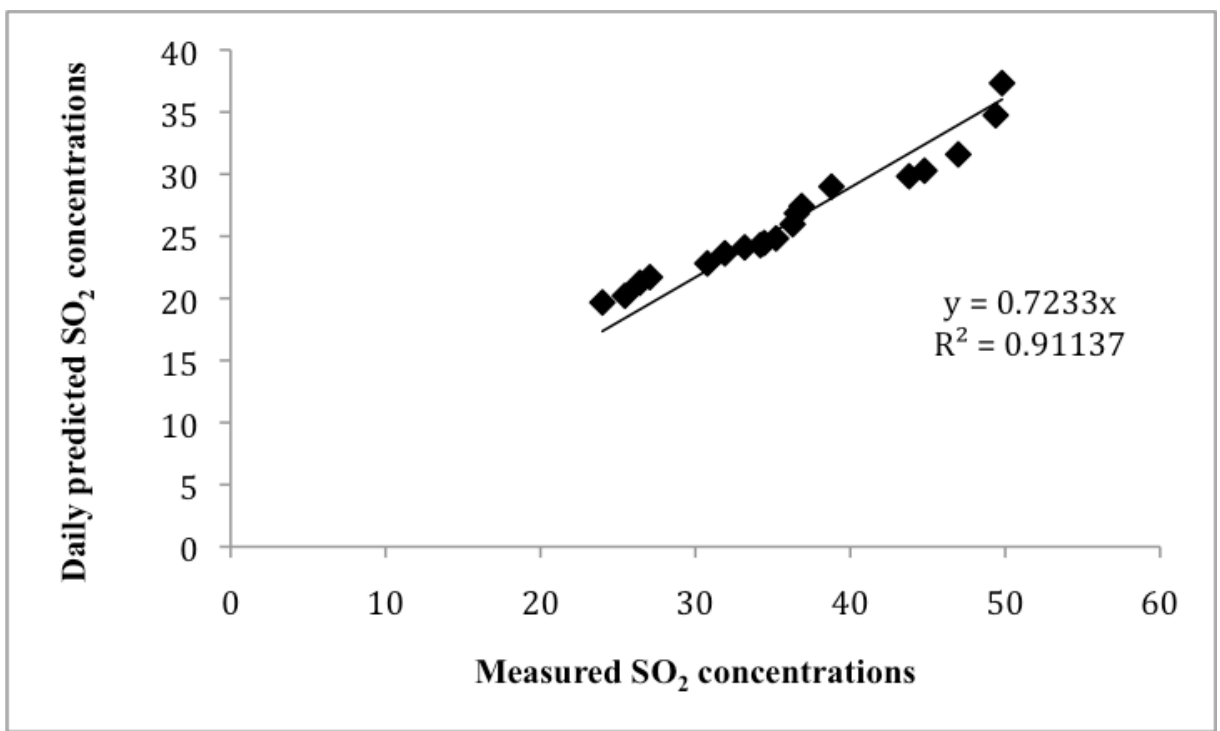

Fig. 2 Daily predicted $\mathrm{SO}_{2}$ concentrations vs. measured $\mathrm{SO}_{2}$ concentrations

The predicted hourly average ground level concentrations of $\mathrm{SO}_{2}$ are compared with Kuwait-EPA Ambient Air Quality Standards (AAQS) at all of the selected receptors.

The maximum allowable level for the hourly average concentration of $\mathrm{SO}_{2}$, specified by Kuwait-EPA, is $444 \mu \mathrm{g} / \mathrm{m}^{3}$. Fig. 3 shows the isopleths of the predicted hourly average ground level concentration of $\mathrm{SO}_{2}$ calculated at the selected uniform grid receptors.
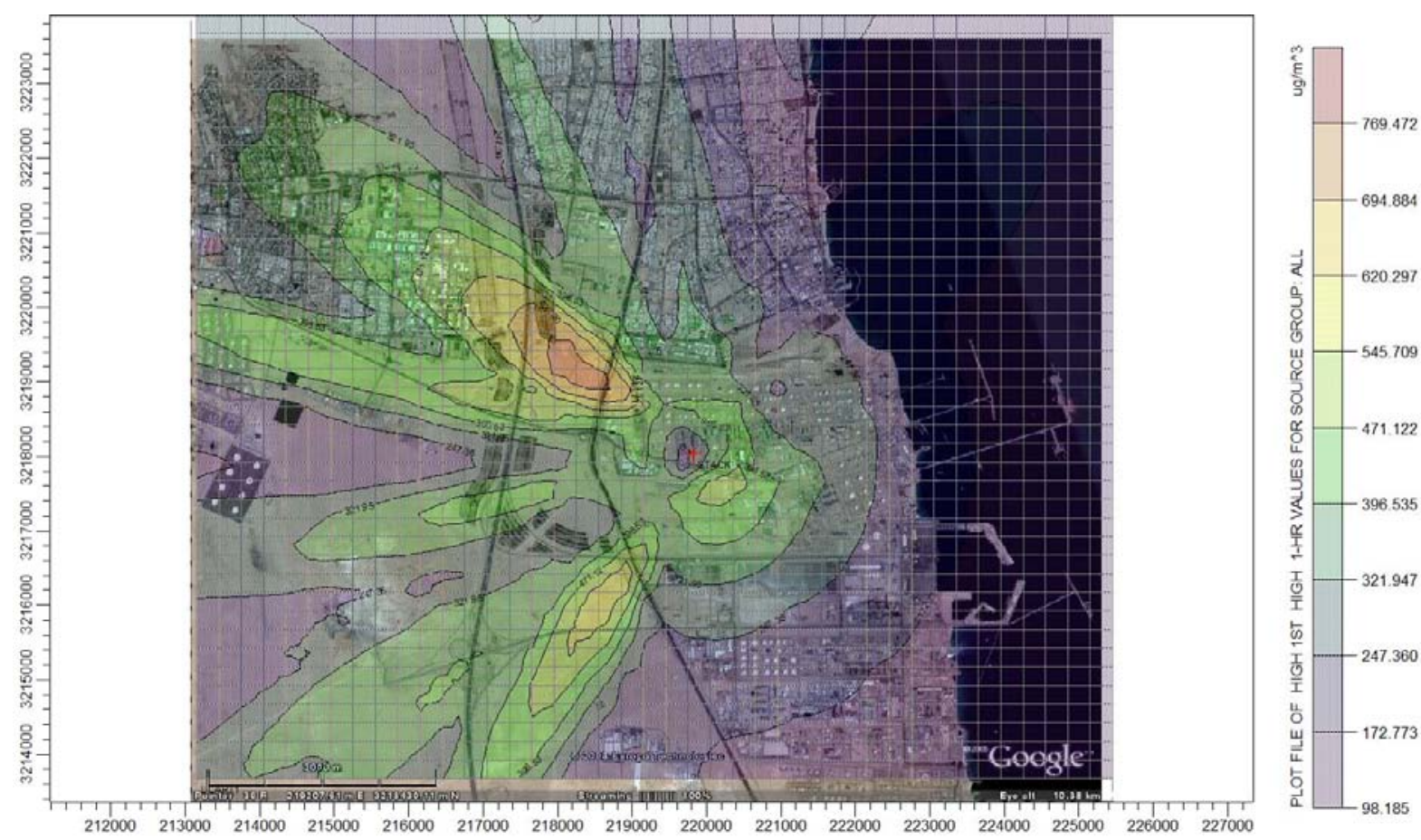

Fig. 3 Isopleths plot of the predicted hourly average ground level concentration of $\mathrm{SO}_{2}$ 
The isopleths indicate the predicted spatial variations of the ground level concentrations of $\mathrm{SO}_{2}$. The maximum predicted hourly average ground level concentration of $\mathrm{SO}_{2}$ in the vicinity of the refinery exceeded by as much as $300 \mu \mathrm{g} / \mathrm{m}^{3}$. The highest predicted concentration is equal to $769 \mu \mathrm{g} / \mathrm{m}^{3}$, observed on the $8^{\text {th }}$ of March 2008 at 8:00 hour and about $1.713 \mathrm{~km}$ in the NW direction from the FCC stack, and not far from the Fahaheel and Ahmadi areas at the receptor coordinates of $\mathrm{X}=218557.94, \mathrm{Y}=3219169$. This high value of the predicted $\mathrm{SO}_{2}$ concentration is expected due to the elevated $\mathrm{SO}_{2}$ emission rate, which resulted from the high sulphur content in the FCC feedstock and other operational conditions and the prevailing meteorological conditions (temperature, humidity, wind speed, wind direction, stability class and planetary boundary layer).

A thorough inspection on fig. 3 indicates that predicted concentrations of $\mathrm{SO}_{2}$ exceed the allowable hourly limit at $5.3 \%$ of the study area from North West and South West direction from the stack.

Similarly, the predicted daily average ground level concentration of $\mathrm{SO}_{2}$ is compared with Kuwait EPA ambient air quality standards at all receptors. The allowable level for the daily average concentration of $\mathrm{SO}_{2}$ is $157 \mu \mathrm{g} / \mathrm{m}^{3}$. Fig. 4 shows the isopleths of the predicted daily average ground level concentration of $\mathrm{SO}_{2}$ computed at the selected uniform grid receptors. 

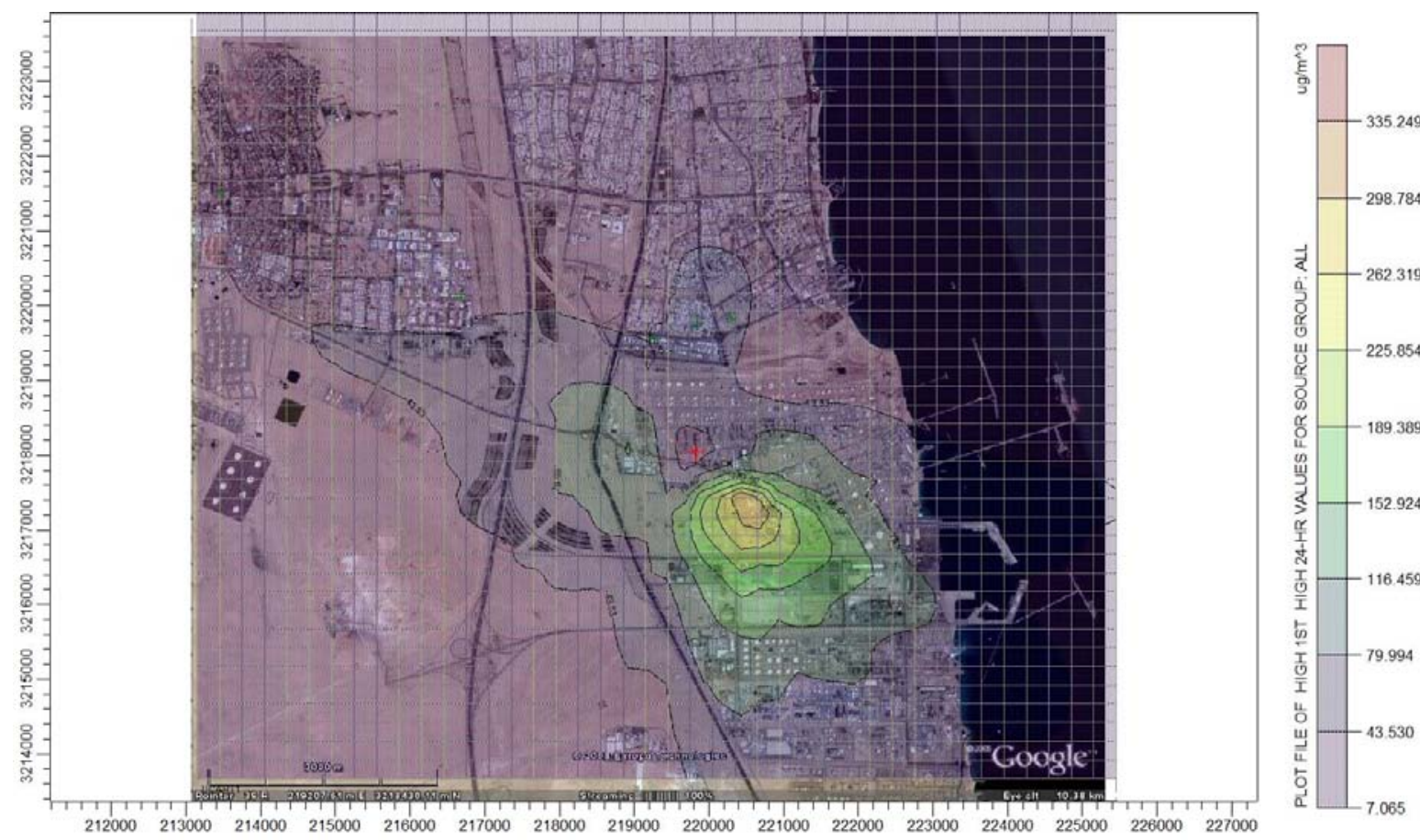

Fig. 4 Isopleths plot of the predicted daily average ground level concentration of $\mathrm{SO}_{2}$

The isopleths indicate the daily predicted spatial variations of the ground level concentrations of $\mathrm{SO}_{2}$ in the area of study. The highest daily predicted concentration is equal to $335 \mu \mathrm{g} / \mathrm{m}^{3}$, observed on the $9^{\text {th }}$ of November 2008 and about $0.75 \mathrm{~km}$ in the SE direction from the stack, at a receptor coordinates of $\mathrm{X}=220357.94, \mathrm{Y}=3217419$ affecting the neighboring Shuaiba industrial area, Kuwait main industrial complex. This high value of the daily predicted $\mathrm{SO}_{2}$ concentration is exceeded the allowable level by $157 \mu \mathrm{g} / \mathrm{m}^{3}$ and obviously influenced by the prevailing meteorological conditions, especially the predominant North West wind and other meteorological factors.

Discrete receptor 2, is located at Petroleum services offices, has shown the highest $\mathrm{SO}_{2}$ hourly concentration equal to $544 \mu \mathrm{g} / \mathrm{m}^{3}$ on $27^{\text {th }}$ February at 8:00 hours. The hourly exceedance is occurred four times at this location throughout the study period. The highest daily concentration at the same receptor is equal to $39 \mu \mathrm{g} / \mathrm{m}^{3}$ on $8^{\text {th }}$ March.

Discrete receptor 3 , is located at school, has shown the highest $\mathrm{SO}_{2}$ hourly concentration equal to $279 \mu \mathrm{g} / \mathrm{m}^{3}$ on $2^{\text {nd }}$ March at 4:00 hours. This concentration is below the Kuwait EPA hourly standards. The daily highest concentration is equal to $57 \mu \mathrm{g} / \mathrm{m}^{3}$ on $2^{\text {nd }}$ 
March.

Discrete receptor 4, is located at Ahmadi hospital, has shown the highest $\mathrm{SO}_{2}$ hourly ground level concentration equal to $288 \mu \mathrm{g} / \mathrm{m}^{3}$ on $27^{\text {th }}$ February at 8:00 hours. This value is also below the specified hourly limit set by Kuwait EPA. The daily predicted concentration is equal to $23 \mu \mathrm{g} / \mathrm{m}^{3}$ on $30^{\text {th }}$ April.

Discrete receptor 5 , is located at shopping area, has shown the highest $\mathrm{SO}_{2}$ hourly ground level concentration is equal to $336 \mu \mathrm{g} / \mathrm{m}^{3}$ on $23^{\text {rd }}$ October at 8:00 hours. The daily predicted concentration is equal to $45 \mu \mathrm{g} / \mathrm{m}^{3}$ on $22^{\text {nd }}$ April. Both hourly and daily predicted values are below Kuwait EPA hourly and daily ambient air quality standards.

Kulkarni et al., (2009) have reported that Lanthanum and Lanthanides are used as markers for particulate matters pollution as $\mathrm{PM}_{2.5}$ in petroleum refineries, mainly from FCC units.

US EPA daily $\mathrm{PM}_{2.5}$ standard is $35 \mu \mathrm{g} / \mathrm{m}^{3}$. In the present work, the application of Aermod to predict ground level concentration of $\mathrm{PM}$ is considered as $\mathrm{PM}_{2.5}$ for rare earth metals i.e. Lanthanum and Cerium. $\mathrm{PM}_{2.5}$ is inhalable and has adverse impact on public health causing cardiovascular diseases. Kuwait EPA has no standard for $\mathrm{PM}_{2.5}$ and has only specified daily and yearly standard for $\mathrm{PM}_{10}$. Figure 5 shows the isopleths of the predicted hourly average ground level concentration of PM calculated at the selected uniform grid receptors. 


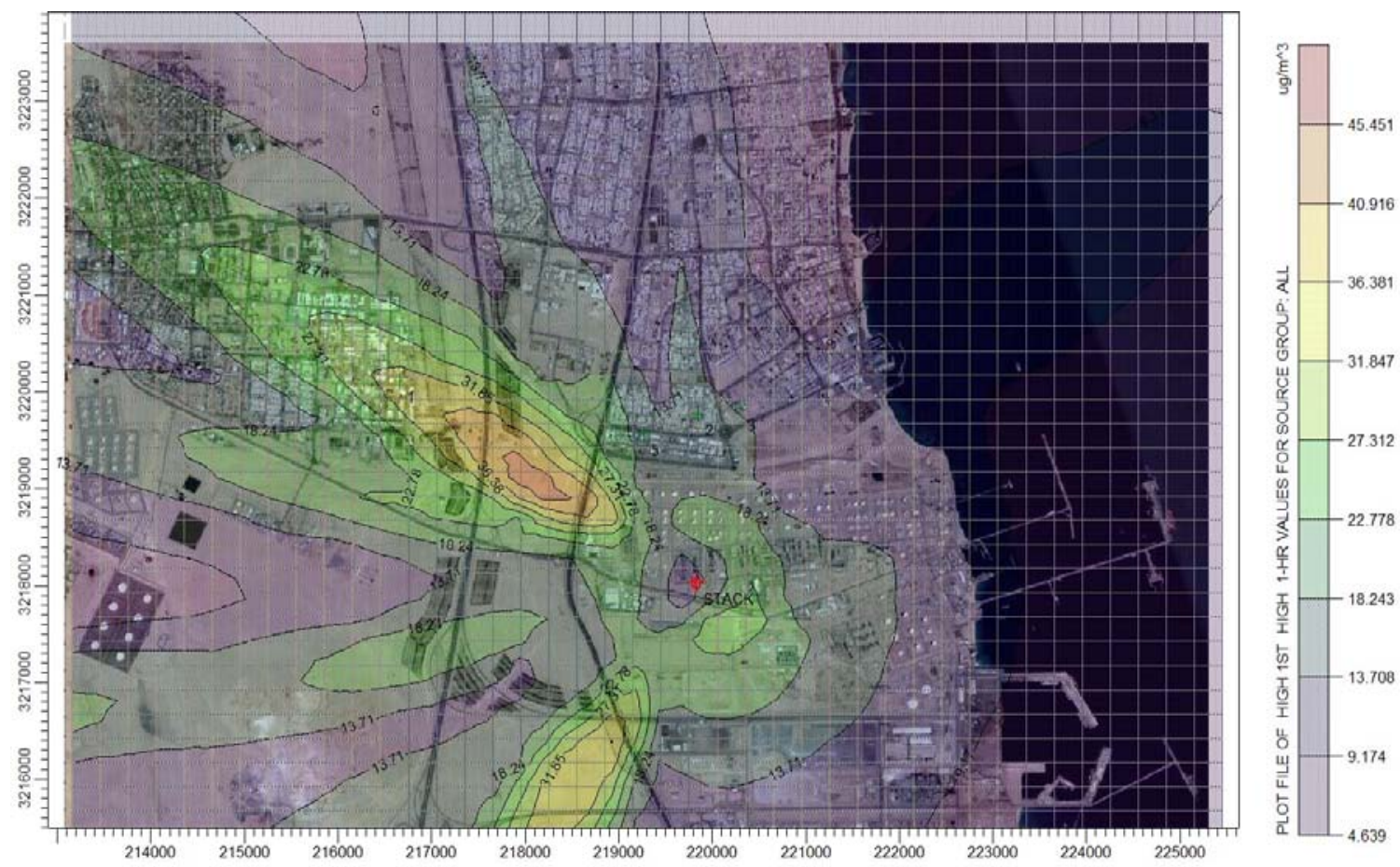

Fig. 5 Isopleths plot of the predicted hourly average ground level concentration of PM

The isopleths indicate the hourly predicted spatial variations of the ground level concentrations of PM. The maximum hourly predicted average ground level concentration of PM is equal to $45 \mu \mathrm{g} / \mathrm{m}^{3}$, observed on the $27^{\text {th }}$ of February 2008 at 8:00 hour and about $1.56 \mathrm{~km}$ in the NW direction from the FCC stack, and at receptor coordinates of $\mathrm{X}=218557.94, \mathrm{Y}=3218919$.

Similarly, the predicted daily average ground level concentration of PM is compared with US EPA ambient air quality standards for $\mathrm{PM}_{2.5}$ at all receptors. Figure 6 shows the isopleths of the predicted daily average ground level concentration of PM computed at the selected uniform grid receptors. 


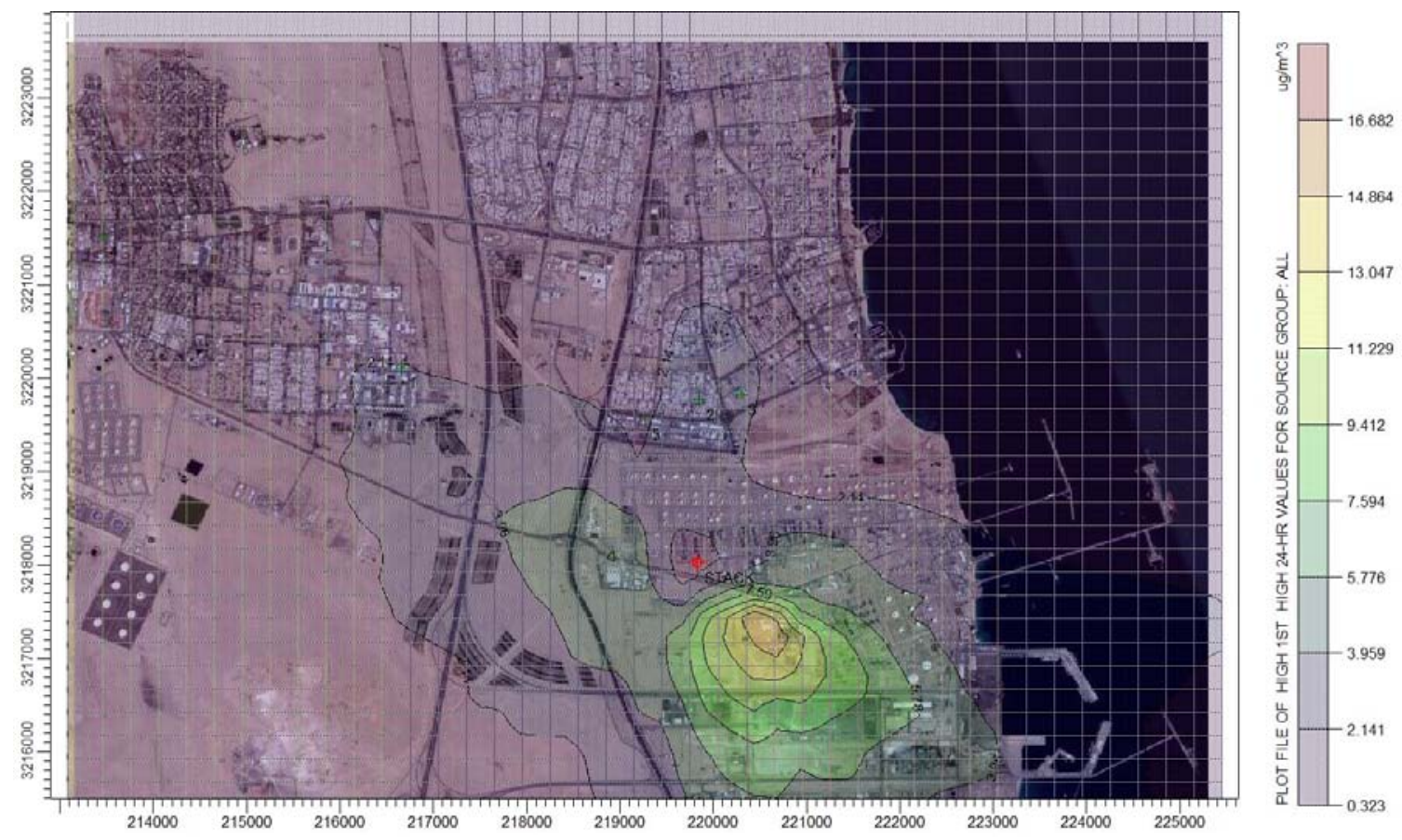

Fig. 6 Isopleths plot of the predicted daily average ground level concentration of PM

The isopleths indicate the daily average predicted spatial variations of the ground level concentrations of PM in the area of study. The highest daily predicted concentration is equal to $16 \mu \mathrm{g} / \mathrm{m}^{3}$, observed on the $29^{\text {th }}$ of December 2008 and about $0.75 \mathrm{~km}$ in the SE direction from the stack, at a receptor coordinates of $\mathrm{X}=220657.94, \mathrm{Y}=3217419$ due to the influence of the prevailing meteorological conditions, especially the predominant North West wind and other meteorological factors.

To observe the computational model sensitivity, another scenario run is performed adding two finer meshes consisting of $21 \times 21$ uniform receptor points, the first one covering hourly highest ground level concentration area, the other one covering daily highest predicted ground level concentration area. The output accuracy has improved for both pollutants due to application of interpolation using small values of $\Delta x=150 \mathrm{~m}, \Delta \mathrm{y}=110$ $\mathrm{m}$ for the first mesh and $\Delta \mathrm{x}=100 \mathrm{~m}, \Delta \mathrm{y}=100 \mathrm{~m}$ for the second mesh. There is $0.65 \%$ increase in the hourly highest ground level concentration and 2.8\% increase in the daily highest ground level concentration, which are insignificant. Therefore, the only parent mesh is used in the computational process for all the other scenarios considered in the parametric studies. 
FCC stack sensitivity analysis is performed on 3 scenarios (stack height, $\mathrm{SO}_{2}$ emission rate and stack diameter).

In scenario 1, analysis for stack heights $50 \mathrm{~m}, 80 \mathrm{~m}, 120 \mathrm{~m}, 160 \mathrm{~m}$ and $200 \mathrm{~m}$ is conducted while keeping the emission rate, exit flue gas velocity, exit temperature and stack diameter constant.

The influence of stack height is shown in fig. 7. It is obvious from the figure that the highest predicted hourly and daily ground level concentrations of $\mathrm{SO}_{2}$ are reduced substantially as stack height is increased. The reduction in the highest computed hourly ground level concentration of $\mathrm{SO}_{2}$ is almost $50 \%$ when stack height is doubled. The decrease in evaluated hourly $\mathrm{SO}_{2}$ concentration as a function of stack height is given as an exponential expression $C\left(\mu \mathrm{g} / \mathrm{m}^{3}\right)=1600.7 e^{-9.071 \times 10^{-3} h}$ and $\mathrm{r}^{2}$ is 0.999 , where $\mathrm{h}$ is the stack height $(\mathrm{m})$. The hourly gradient $\mathrm{dC} / \mathrm{dh}=14.52 e^{-9.071 \times 10^{-3} h}$ becomes insignificant at higher stack elevations. The highest daily predicted ground level concentration as a function of stack height is given as $C\left(\mu \mathrm{g} / \mathrm{m}^{3}\right)=1409.8 e^{-1.732 \times 10^{-2} h}$ and $\mathrm{r}^{2}$ is 0.984 . The daily highest prdicted concentration gradient is $\mathrm{dC} / \mathrm{dh}=24.42 e^{-1.732 \times 10^{-2} h}$. The locations of hourly highest predicted concentrations of $\mathrm{SO}_{2}$ from the stack, as a function of stack height is shown in figure 7 and related as $D(k m)=0.597 e^{1.16 \times 10^{-2} h}$ and $r^{2}$ is 0.978 . 


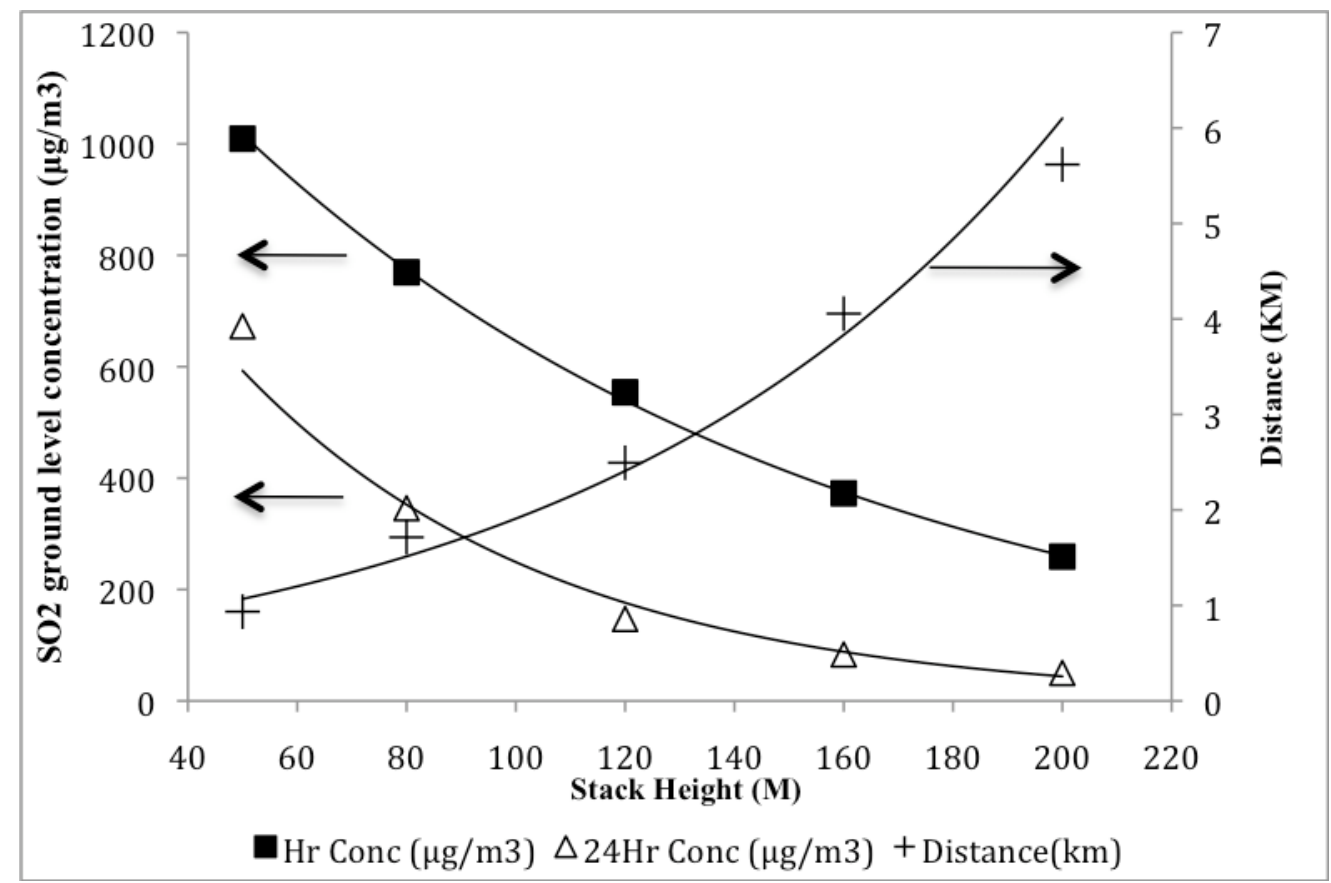

Fig. 7 Stack height vs. hourly and daily predicted ground level concentrations of $\mathrm{SO}_{2}$

In scenario 2, $\mathrm{SO}_{2}$ emission rate effect from FCC stack is tested at stack height of $80 \mathrm{~m}$ for different total monthly emission rates of 3000 g/s, 4000 g/s, 5000 g/s, 6000 g/s, 7000 $\mathrm{g} / \mathrm{s}$ and $8000 \mathrm{~g} / \mathrm{s}$, taking into consideration the monthly emission variations (by using emission factors, table 2) and fixing other stack parameters i.e. exit temperature, exit flue gas velocity and stack diameter.

It is noticed from fig. 8 that the highest predicted hourly and daily ground level concentrations of $\mathrm{SO}_{2}$ is substantially decreased as $\mathrm{SO}_{2}$ emission rate is reduced. At $50 \%$ reduction in the emission rate, the highest hourly and daily ground level concentrations decreased by $50 \%$. 


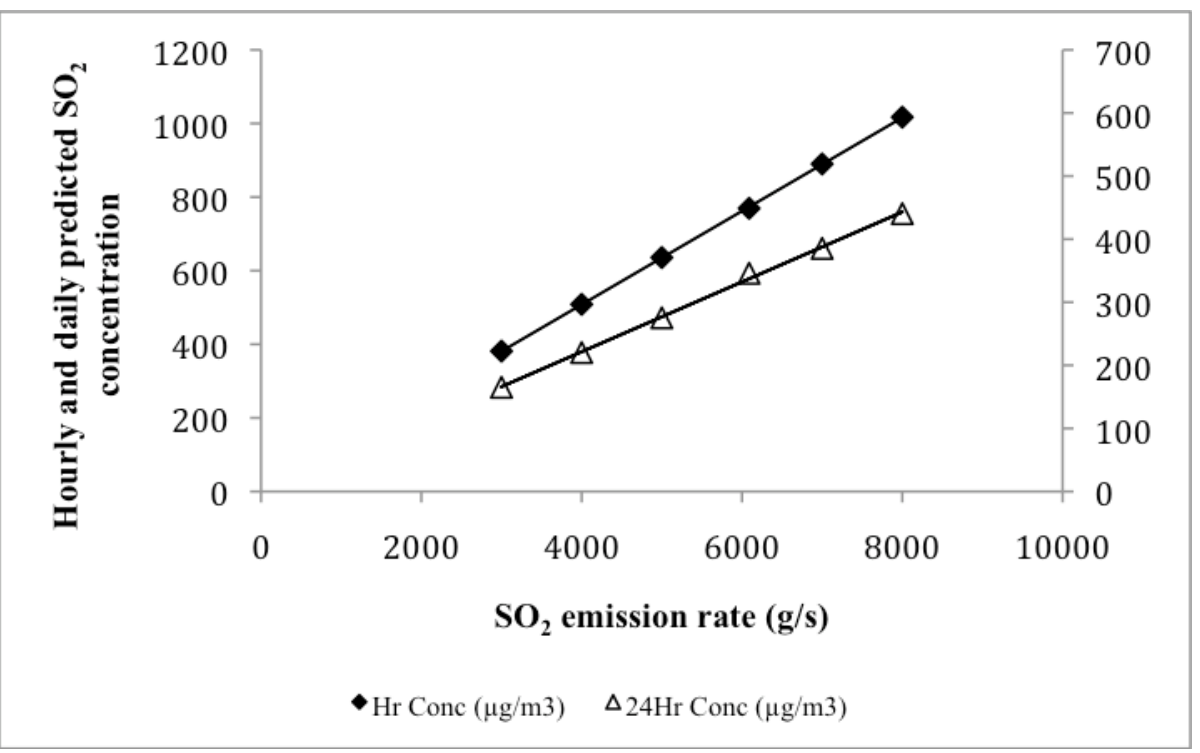

Fig. $8 \mathrm{SO}_{2}$ emission rate vs. hourly and daily predicted $\mathrm{SO}_{2}$ ground level concentrations

In scenario 3, FCC stack diameter effect is examined at stack height of $80 \mathrm{~m}$ for different diameters of $1.5 \mathrm{~m}, 2.3 \mathrm{~m}, 3 \mathrm{~m}$ and $4 \mathrm{~m}$. The exit flue gas velocity is also changed as directly related to the square of the diameter for a fixed exit flue gas flow rate. It is observed that the dispersion and rise of the plume are not affected by diameter variation and the predicted ground level concentration of $\mathrm{SO}_{2}$ remained almost unaltered. The hourly and daily predicted concentrations of $\mathrm{SO}_{2}$ are almost identical for all the cases. 


\section{Conclusion}

FCC unit in a refinery is major contributor of $\mathrm{SO}_{2}$ and $\mathrm{PM}$ emissions those are responsible for adverse impact on the immediate neighborhood of the refinery. A complete comprehensive emission inventories for a year long period have been prepared for both $\mathrm{SO}_{2}$ and Particulate Matters.

A model run performed for actual monthly emission variation with total $\mathrm{SO}_{2}$ emission rate of $6089.2 \mathrm{~g} / \mathrm{s}$ and total PM emission rate of $302 \mathrm{~g} / \mathrm{s}$ independently, taking into consideration monthly emission factors for both pollutants. The daily predicted ground level concentrations of $\mathrm{SO}_{2}$ are compared with Kuwait EPA monitoring station daily measured $\mathrm{SO}_{2}$ concentrations at the same discrete receptor and showed acceptable validation of the model output.

The highest hourly predicted concentration of $\mathrm{SO}_{2}$ is equal to $769 \mu \mathrm{g} / \mathrm{m}^{3}$. It is observed on the $8^{\text {th }}$ of March 2008 at 8:00 hour, due to elevated $\mathrm{SO}_{2}$ emission rate in this month and the prevailing meteorological conditions, especially sea breeze effect in the early morning hours. The highest daily predicted concentration is equal to $335 \mu \mathrm{g} / \mathrm{m}^{3}$. It is observed on the $9^{\text {th }}$ of November 2008, and obviously influenced by the predominant North West wind and high $\mathrm{SO}_{2}$ emission rate in the month of November.

The maximum hourly predicted average ground level concentration of PM is equal to 45 $\mu \mathrm{g} / \mathrm{m}^{3}$. It is observed on the $27^{\text {th }}$ of February 2008 at 8:00 hour. The highest daily predicted concentration is equal to $16 \mu \mathrm{g} / \mathrm{m}^{3}$, observed on the $29^{\text {th }}$ of December 2008.

The stack sensitivity is explored by changing stack height, total emission rate and stack diameter independently. It is observed that the higher stack facilitated good dispersion, thus lowering the ground level average concentration of the pollutant up to $50 \%$ when the stack height doubled.

It is notice that the highest predicted hourly and daily ground level concentrations of $\mathrm{SO}_{2}$ are substantially decreased as $\mathrm{SO}_{2}$ emission rate is reduced. At $50 \%$ reduction in the emission rate, the highest hourly and daily ground level concentrations decreased by almost 48\%. 
The influence of stack diameter inherently changed the exit flue gas velocity due to invariable flue gas flow-rate. The plume rise and dispersion are related to the exit flue gas velocity, which decreased with the increase of stack diameter because of proportionality to the square of diameter. For a fixed load there is no noticeable change in the average hourly and daily predicted ground level concentrations of $\mathrm{SO}_{2}$. 


\section{References}

Abdul Wahab S. A., Al-Alawi S.M., El-Zawahri A. (2002), "Patterns of $\mathrm{SO}_{2}$ emissions: a refinery case study” Environmental Modeling and Software 17 563-570

Alrashidi M. S., Nassehi V., Wakeman R. J. (2005), “Investigation of the efficiency of the existing air pollution monitoring sites in the state of Kuwait” Environmental Pollution 138 219-229

Caputo M., Gimenez M., SchlampM. (2003), "Inter-comparison of atmospheric dispersion models” Atmospheric Environment 37, 2435-2449

Google Inc. 2010 “Google Earth” Version 5.1, http:// www.earth.google.com

Isakov V., Venkatram A, Touma S. J, Koracin.D,Otte L. T. (2007) "Evaluating the use of outputs from comprehensive meteorological models in air quality modeling applications” Atmospheric Environment 41, 1689-1705

Kesarkar A. P., Dalvi M., Kaginalkar A., Ojha A. (2007) "Coupling of the Weather Research and Forecasting Model with AERMOD for pollutant dispersion modeling. A case study for $\mathrm{PM}_{10}$ dispersion over Pune, India” Atmospheric Environment 41, 19761988

Kulkarni P., Chellam S., Fraser M. P. (2009) “Tracking Petroleum Refinery Emission Events Using Lanthanum and Lanthanides as Elemental Markers for $\mathrm{PM}_{2.5}$ ” Environmental Science and Technology, 43 (8), 2990-2991, 2009.

Lopez J. L., C. Mandujano (2005) "Estimation of the impact in the air quality by the use of clean fuels (fuel oil versus natural gas)” Catalysis Today 106, 176-179

Rama Krishna T.V.B.P.S., Reddy M.K., Reddy R.C., Singh R.N., (2004) “Assimilative capacity and dispersion of pollutants due to industrial sources in Visakhapatnam bowl area” Atmospheric Environment 38, 6775-6787

Venkatram A., Isakov V., Yuana J., Pankratza D. 2004 "Modeling dispersion at distances of meters from urban sources” Atmospheric Environment 38, 4633-4641 
Yateem W., Nassehi V., Khan A. R., (2010) "Inventories of $\mathrm{SO}_{2}$ and $\mathrm{PM}$ emissions from Fluid Catalytic Cracking (FCC) units in petroleum refineries”, Water, Air \& Soil pollution, DOI: 10.1007/s11270-010-0423-z. 